\title{
The Role of Advertising in Consumer Decision Making
}

\author{
Dr. D.Prasanna Kumar \& K. Venkateswara Raju \\ Associate Professor, K L U Business School, Guntur, Andhra Pradesh, India \\ Research Scholar, K L U Business School, Guntur, Andhra Pradesh, India
}

\begin{abstract}
Advertising is a form of communication intended to convince an audience (viewers, readers or listeners) to purchase or take some action upon products, information or services etc. The purchase process is a decision - making process under risk. This paper investigates the relationship between independent variables which are emotional response with attitudinal and behavioral aspect of consumer buying behavior, by tapping the responses of 110 respondents. The basic objective of this research is to assess the influence of advertising through attitudinal buying behavior of consumer (male \& female) and analyze the influence of Advertising between male and female.
\end{abstract}

Key Words: Advertising, Consumer behavior, Consumer buying behavior.

\section{Introduction}

Almost every one grows up in the world which is flooded with the mass media e.g. television, advertising, films, videos, billboards, magazines, movies, music, newspaper, and internet. Of all marketing weapons, advertising is renowned for its long lasting impact on viewer's mind, as its exposure is much broader. Advertising is a subset of promotion mix which is one of the 4P's in the marketing mix i.e. product, price, place and promotion. As a promotional strategy, advertising serves as a major tool in creating product awareness in the mind of a potential consumer to take eventual purchase decision. Advertising, sales promotion and public relations are mass-communication tools available to marketers. Advertising through all mediums influence audiences, but television is one of the strongest medium of advertising and due to its mass reach; it can influence not only the individual's attitude, behavior, life style, exposure and in the long run, even the culture of the country.

The evolution of advertisement dates back into the ancient times. Societies used symbols, and pictorial signs to attract their product users. Over centuries, these elements were used for promotion of products. In the early ages, these were handmade and were produced at limited scale for promotions. Later on, this phenomenon gained strength more intensively for promotional purposes. Today's modern environment, advertisements have become one of the major sources of communicational tool between the manufacturer and the user of the products.

A company cannot make dream to be a well known brand until they invests in their promotional activities, for which consumer market have been dominating through advertisements. As the primary mission of advertiser is to reach prospective customers and influence their awareness, attitudes and buying behavior. They spend a lot of money to keep individual's interest in their products. They need to understand what makes potential customers behave the way they would like. It also appears that advertising may have the potential to contribute to brand choice among consumers.

The major aim of advertising is to impact on buying behavior; however, this impact about brand is changed or strengthened frequently in people's memories. Memories about the brand consist of those associations that are related to brand name in consumer mind. These brand cognition influence consideration, evaluation, and finally purchases. The principal aim of consumer behavior analysis is to explain why consumers act in particular ways under certain circumstances. It tries to determine the factors that influence consumer behavior, especially the economic, social and psychological aspects. When young people choose advertising information and characters as their role models, they may not only identify with them but also intend to copy them in terms of how they dress and what they are going to buy.

Traditional hierarchy-of-effects models of advertising state that advertising exposure leads to cognitions, such as memory about the advertisement, the brand; which in turn leads to attitudes, i.e. Product liking and attitude toward purchase; which in the end leads to behaviors, like buying the advertised product. As the market is surplus with several products or services, so many companies make similar functional claim; so, it has become extremely difficult for companies to differentiate their products or services based on functional attributes alone. Differentiations based on functional attributes, which are shown in advertisement, are never long lasting as the competitors could copy the same. Therefore, the marketers give the concept of brand image. Like by creating the character of the caring mother, the marketer injects emotion into the consumer's learning 
and process of advertisements. Doing so advertiser creates those types of advertisements, which carry emotional bond with consumer.

Therefore, that consumer is more likely to associate with advertisements of those brands, which have emotional values and messages. Because, positive emotional appeals also provide a strong brand cue and stimulate category-based processing. If the categorization process is successful, then the affect and beliefs associated with this category in memory are transferred to the object itself. Consumers are not only at first confused and disordered in mind, but they also try to categorize the brand association with their existing memory, when thousands of products are faced by them, and they might reposition memories to outline a brand image and perception / concept toward new products. They can categorize latest information into particular brand or product group label and store them accordingly. This procedure is not only associated to consumer's familiarity and information, but also attachment and preference of brand. It is also suggested that consumer can disregard or prevail over the dissonance from brand extension.

In today's dynamic world, it is almost impossible for advertisers to deliver advertising message and information to buyers without use of advertising. Certainly, this may be because of the globalization and accessibility of hundreds of channels for the viewers of this modern era. Now a day, due to globalized economy, this made available a bulk of marketing stimuli to the modern consumers. More often consumerism describes the way of equating personal happiness, with purchasing material possessions and consumption in excess of one's need.

This research is based on attitudinal behavior of male and female in different buying behavior. The basic objectives of this research are to assess the advertising through attitudinal buying behavior consumer and analyze the influence of advertising through buying behavior consumer.

\section{Literature Review}

Numerous studies have examined the effectiveness of advertising in the past decade. The common measures of advertising effectiveness include ad recall, ad recognition, brand awareness, clicks or click through rate, attitude towards the ad and the brand, and purchase consideration. Of these common measures, attitudes toward the ad, clicks on ad, and ability to recall ad are the focus of the present study. The effectiveness of these three measures was assessed by their ability to predict purchase decision.

Advertising, sales promotion and public relations are mass-communication tools available to marketers. As its name suggests, mass communication uses the same message for everyone in an audience. Today, definitions of advertising abound. We might define it as communication process, a marketing process, an economic and social process, a public relations process or information and persuasion process viewed advertising from its functional perspectives, hence they define it as a paid, non-personal communication through various media by business firms, non-profit organization, and individuals who are in some way identified in the advertising message and who hope to inform or persuade members of a particular audience is of the opinion that advertising is used to establish a basic awareness of the product or service in the mind of the potential customer and to build up knowledge about it.

Technology advancement had not given us new products and services, but they had changed the meaning of many words. With increase in mass media, advertising effectiveness, as more traditional mass media, had reduced. Now advertiser is looking for new and presumably less cluttered media. The current age of digital media had given consumer choices to opt in and opt out of marketing messages and advertising. Consumers are getting more control of what they want and when they want. All these things are moving toward the interactive marketing.

As a promotional strategy, advertising provides a major tool in creating product awareness and condition the mind of a potential consumer to take final purchase decision. As advertiser's primary mission is to reach potential customers and influence their awareness, attitudes and buying behavior. Ayanwale et al (2005) conducted research on advertisement of Bournvita, he found as advertising has a major influence on consumers' likeness for Bournvita food drink. Similar researches have already been conducted for the quality of Bournvita.

\section{Objectives of the Study:}

1. To study the impact of advertisements on the consumer segment.

2. Impact of advertisements on the consumer buying segment.

3. To evaluate the role of advertisements in the common man's life.

4. To study factors affecting the consumer buying process with respect to advertisements

\section{Scope of Study:}

The Inferences from the study are based on the responses given by the consumers in a specific area. This study will be helpful in getting an insight into the perception of Consumers on Advertisements. 


\subsection{Research design}

\section{Research Methodology}

The study is based on both primary data and secondary data. The primary data was collected through structured questionnaire for which samples of 110 respondents were selected for this study. The collected samples using convenient sampling method was validated and took it for further analysis. Secondary data is also been collected from database sites and articles.

The collected data were analyzed with the suitable tools like Chi - Square tools with the following assumptions were made on the onset of the project.

Research Model:

Research model proposed is as under:

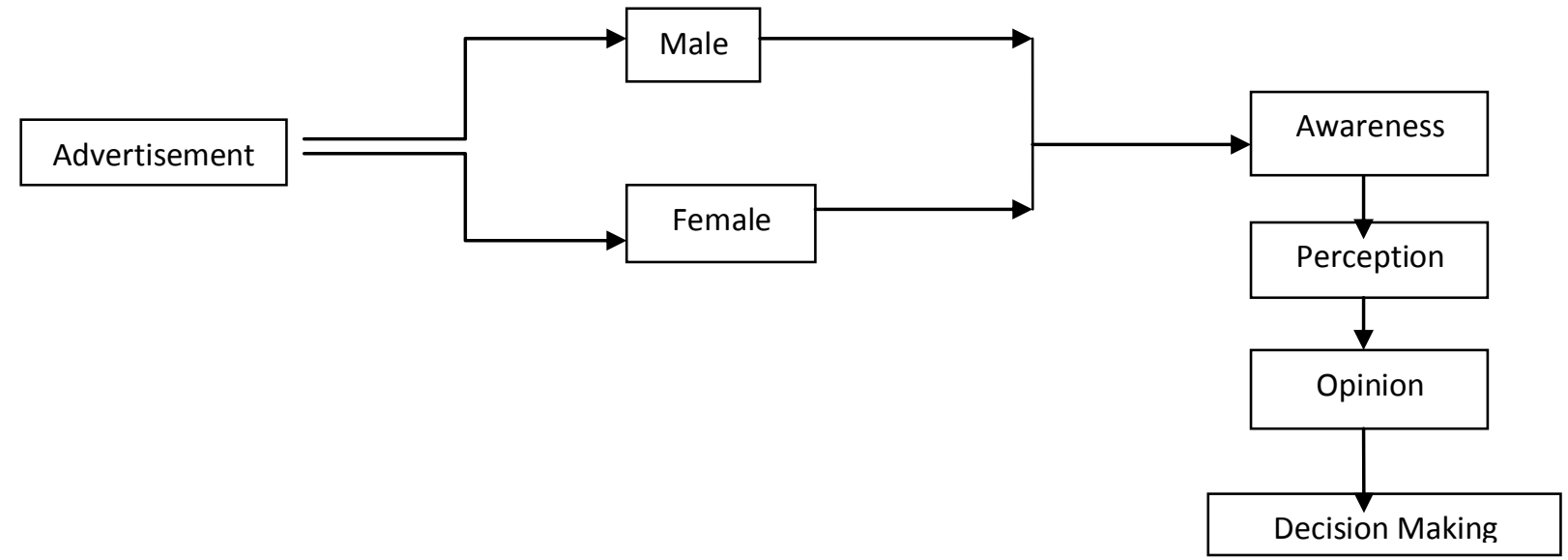

The research design clear examines the relationship between the advertisements in between male and female and the effect of those advertisements on their purchase decision making.

The advertisements directly have effect on the consumer; they invoke the pleasure of buying the product irrespective of the cost. The most important task is promoting any new product is to create awareness perception - that the product exists.

The second important task is to provide enough information - learning - about the product for the prospective customer to make an informed decision. Finally, the marketer wants to be persuasive enough to stimulate the customer's desire - motivation - to satisfy his or her needs or wants by purchasing and repurchasing the product.

\subsection{Area of the study}

The respondents are randomly selected for this study.

\subsection{Research approach}

\section{Customer Survey and questionnaires method}

Survey method is used for collecting data from consumers of various goods at retail outlets. We requested all respondents to fill in the questionnaire, by self after explaining the various aspects mentioned in it. It contained both open and closed ended questions in a structured format very easy to understand on the first look.

\subsection{Sampling Technique}

A convenient sample (non - probability sampling method) of 110 consumers was shared up for the current study in which respondent of the study was request to complete the questionnaire on voluntary basis.

\subsection{Sample Size}

The Size of the sample taken in this study is 110 .

5.6 Period of Study

The study was done during September 2013 to October 2013 timeline.

\subsection{Data Usage:}

For analysis and interpretation, only primary data is used. However for conclusion and recommendations both primary and the secondary data along with the verbal knowledge and information although obtained from respondents, though they are outside the parameters of questionnaire were also included. The data collected from these sources were analyzed using various tools like percentage analysis, chi-square test, cross table analysis method. 


\subsection{Research Instrument:}

The data is collected by well developed, structured five point Likert Scale is considered. All of the questionnaires were distributed among the respondents in the defined areas. The data is collected in a period of 5 days and the responses were fed into the Statistical Package for Social Science (SPSS) version 20.0 of IBM for analysis and evaluation.

The questionnaire has been classified into two parts such as part I and part II. Part I explains the awareness about the advertisements and the part two describes the recent purchase the customers had done with the help of the advertisements they have seen. Here the Likert scale has been considered which consists of 5 point scale where 5 as strongly disagree and 1 as strongly agrees.

For the analysis of the responses, under the five point Likert Scale, it is defined as

- Strongly agree (1 point)

- Agree (2 point)

- No opinion (3 point)

- Disagree (4 point)

- Strongly disagree (5 point)

5.9 Tools:

Frequencies and cross tabulation have been calculated for the responses of the respondents. Chi Square test analysis was conducted on the data of part II in questionnaire.

\subsection{General Profile of the Respondents}

\section{Analysis and Interpretation}

\begin{tabular}{|c|c|c|c|c|c|c|c|}
\hline \multirow{2}{*}{ SEX } & Male & Female & & & & & \\
\hline & 44 & 56 & & & & & \\
\hline \multirow{2}{*}{ AGE } & $15-20$ & $21-30$ & $31-45$ & $46-55$ & $>55$ & & \\
\hline & 16 & 22 & 22 & 21 & 19 & & \\
\hline \multirow{2}{*}{ Prefered mode of receiving Advertisement } & Print & TV & Radio & Mobile & Internet & All & \\
\hline & 25 & 41 & 6 & 12 & 13 & 4 & \\
\hline \multirow{4}{*}{ Types of ads } & Funny & Creative & Unique & Informative & Meaningful & Short and crisp & Off beat \\
\hline & 17 & 23 & 10 & 6 & 20 & 3 & 2 \\
\hline & Inoffensive & Emotional & Crazy & Simple & Genuine & Straight forward & \\
\hline & 1 & 4 & 6 & 4 & 2 & 3 & \\
\hline
\end{tabular}

\section{Interpretation:}

From the above table, we infer that $44 \%$ of the total respondents are male and $56 \%$ are female. On further classification according to age group, we find that of all the respondents $16 \%$ are $15-20$ years old, $22 \%$ are of the age group $21-30,22 \%$ of the age group $31-45,21 \%$ are of the age group $46-55$ and $19 \%$ are above 55 years. From the responses collected PRINT (25\%), TV (41\%) are the major media that are carrying the Advertisements to the consumers. Most of the respondents feel that advertisements are Funny (17\%), Creative $(23 \%)$ and Meaningful $(20 \%)$.

\subsection{Respondents views about Advertisements:}

Table6.2

\begin{tabular}{|c|c|c|c|c|c|}
\hline PARAMETER & SA & A & NO & DA & SDA \\
\hline Are you interested in watching good ads? & 42 & 41 & 22 & 3 & 2 \\
\hline Do You watch new Ads only? & 44 & 47 & 12 & 6 & 1 \\
\hline Do you think some Ads are extremely annoying? & 43 & 33 & 29 & 2 & 3 \\
\hline Do you Like offbeat ads? & 38 & 31 & 34 & 4 & 3 \\
\hline Do you think Ads are Creative but sensible? & 30 & 25 & 16 & 22 & 17 \\
\hline Do Ads have some message? & 40 & 38 & 32 & $\mathbf{0}$ & $\mathbf{0}$ \\
\hline There are Benefits from the ads? & 44 & 20 & 29 & 14 & 3 \\
\hline Do Ads have some effect on you? & 36 & 44 & 30 & $\mathbf{0}$ & $\mathbf{0}$ \\
\hline Are Ads Visually appealing and engaging? & 38 & 45 & 27 & $\mathbf{0}$ & $\mathbf{0}$ \\
\hline Is the Duration of the Ad Ok? & 17 & 20 & 21 & 25 & 27 \\
\hline Is the Ad able to Convey the intended message? & 20 & 24 & 24 & 23 & 19 \\
\hline
\end{tabular}


Figure 6.3

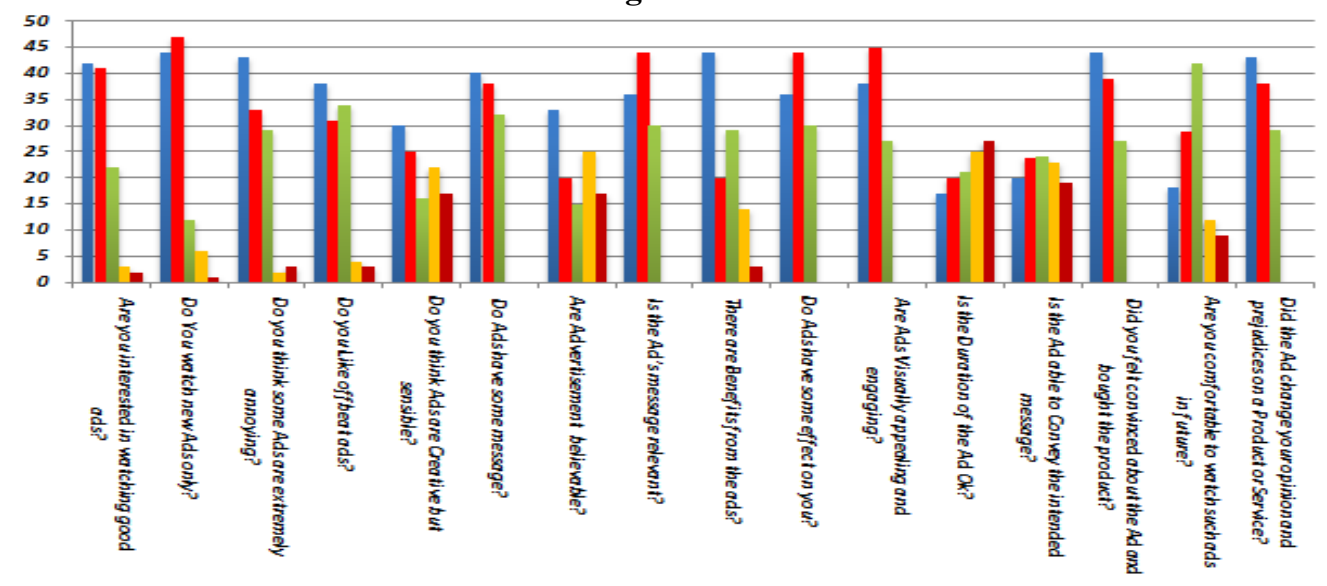

6.4 Chi-Square Test

6.4.1. Is There a Relation between AGE and EFFECT OF THE AD ON THE RESPONDENT?

Case Processing Summary

\begin{tabular}{|c|c|c|c|c|c|c|}
\hline \multirow{2}{*}{} & \multicolumn{4}{|c|}{ Cases } \\
\cline { 2 - 7 } & \multicolumn{2}{|c|}{ Valid } & \multicolumn{2}{c|}{ Missing } & \multicolumn{2}{c|}{ Total } \\
\cline { 2 - 7 } & $N$ & Percent & $N$ & Percent & $N$ & Percent \\
\hline AGE * ADEFFECT & 110 & $100.0 \%$ & 0 & $.0 \%$ & 110 & $100.0 \%$ \\
\hline
\end{tabular}

AGE * ADEFFECT Crosstabulation

CHI-SQUARE:

\begin{tabular}{|c|c|c|c|c|c|}
\hline & & \multicolumn{3}{|c|}{ ADEFFECT } & \multirow[b]{2}{*}{ Total } \\
\hline & & 1 & 2 & 3 & \\
\hline \multirow[t]{5}{*}{ AGE } & 1 & 6 & 6 & 6 & 18 \\
\hline & 2 & 8 & 10 & 6 & 24 \\
\hline & 3 & 6 & 11 & 7 & 24 \\
\hline & 4 & 9 & 9 & 5 & 23 \\
\hline & 5 & 7 & 8 & 6 & 21 \\
\hline Total & & 36 & 44 & 30 & 110 \\
\hline
\end{tabular}

\begin{tabular}{|c|c|c|c|c|c|c|c|}
\hline \multicolumn{4}{|c|}{ AGE } & \multirow{2}{*}{\multicolumn{4}{|c|}{ ADEFFECT }} \\
\hline & Observed $N$ & Expected N & Residual & & & & \\
\hline 1 & 18 & 22.0 & -4.0 & & Observed $N$ & Expected $N$ & Residua \\
\hline 2 & 24 & 22.0 & 2.0 & 1 & 36 & 36.7 & -.7 \\
\hline $\begin{array}{l}3 \\
4\end{array}$ & $\begin{array}{l}24 \\
23\end{array}$ & $\begin{array}{l}22.0 \\
22.0\end{array}$ & $\begin{array}{l}2.0 \\
1.0\end{array}$ & 2 & 44 & 36.7 & 7.3 \\
\hline 5 & $\begin{array}{l}23 \\
21\end{array}$ & $\begin{array}{l}22.0 \\
22.0\end{array}$ & -1.0 & 3 & 30 & 36.7 & -6.7 \\
\hline Total & 110 & & & Total & 110 & & \\
\hline
\end{tabular}

Test Statistics

\begin{tabular}{|l|r|r|}
\hline & \multicolumn{1}{|c|}{ AGE } & ADEFFECT \\
\hline Chi-Square & $1.182^{2}$ & $2.691^{\circ}$ \\
df & 4 & 2 \\
Asymp. Sig. & .881 & .260 \\
\hline
\end{tabular}

a. 0 cells $(0 \%$ ) have expected frequencies less than 5 . The minimum expected cell frequency is 22.0 .

b. 0 cells $(0 \%)$ have expected frequencies less than 5 . The minimum expected cell

From the above SPSS calculation we infer that there is a significant relation between AGE and EFFECT OF THE AD ON THE RESPONDENT.

6.4.2. Is There a Relation between CREATIVITY IN THE AD and IN ITS ABILITY IN MAKING THE AD VISUALLY APPEALING AND ENGAGING?

CREATMTY * MSUALAPPEALING Crosstabulation

\begin{tabular}{|ll|r|r|r|r|}
\hline \multirow{2}{*}{ count } & \multicolumn{3}{|c|}{ VISUALAPPEALING } & \multirow{2}{*}{ Total } \\
\cline { 3 - 7 } & & 1 & 2 & 3 & 30 \\
CREATIVITY & 1 & 11 & 13 & 5 & 25 \\
& 2 & 12 & 8 & 5 & 16 \\
& 3 & 5 & 5 & 5 & 22 \\
& 4 & 5 & 11 & 6 & 17 \\
Total & 5 & 5 & 7 & 5 & 110 \\
\hline
\end{tabular}


CHI-SQUARE:

\begin{tabular}{|c|c|c|c|c|c|c|c|}
\hline \multicolumn{4}{|c|}{ CREATINTY } & & & & \\
\hline & Observed $N$ & Expected N & Residual & \multicolumn{4}{|c|}{ VSUALAPPEALING } \\
\hline $\begin{array}{l}1 \\
2\end{array}$ & $\begin{array}{l}30 \\
25\end{array}$ & $\begin{array}{l}22.0 \\
22.0\end{array}$ & $\begin{array}{l}8.0 \\
3.0\end{array}$ & & Observed $N$ & Expected N & Residual \\
\hline 3 & 16 & 22.0 & -6.0 & 1 & 38 & 36.7 & 1.3 \\
\hline 4 & 22 & 22.0 & 0 & 2 & 45 & 36.7 & 8.3 \\
\hline 5 & 17 & 22.0 & -5.0 & 3 & 27 & 36.7 & -9.7 \\
\hline Total & 110 & & & Total & 110 & & \\
\hline
\end{tabular}

Test Statistics

\begin{tabular}{|l|r|r|}
\hline & CREATIVITY & VISUALAPPE \\
\hline Chi-Square & 6.0917 & $4.491^{\circ}$ \\
df & 4 & 2 \\
Asymp. Sig. & .192 & .106 \\
\hline
\end{tabular}

a. 0 cells (0\%6) have expected frequencies less than 5 . The minimum expected cell

b. o cells $(0 \%)$ have expected frequencies less than 5 . The minimum expected cell

From the above SPSS calculation we infer that there is a significant relation between CREATIVITY IN THE AD and IN ITS ABILITY IN MAKING THE AD VISUALLY APPEALING AND ENGAGING.

\subsubsection{Is There a Relation between AGE and RESPONDENTS FEELING THE PRESENCE OF} MESSAGE IN THE AD?

AGE * MESSAGEPRESENTINAD Crosstabulation

\begin{tabular}{|rl|r|r|r|r|}
\hline \multirow{2}{*}{} & \multicolumn{3}{|c|}{ MESSAGEPRESENTINAD } & \multirow{2}{*}{ Total } \\
\cline { 3 - 6 } & 1 & 2 & 3 & 18 \\
\hline AGE & 1 & 6 & 5 & 7 & 24 \\
& 2 & 9 & 9 & 6 & 24 \\
& 3 & 11 & 8 & 5 & 23 \\
& 4 & 7 & 10 & 6 & 21 \\
& 5 & 7 & 6 & 8 & 110 \\
\hline
\end{tabular}

CHI-SQUARE:

\begin{tabular}{|c|c|c|c|c|c|c|c|}
\hline & Observed N & Expected N & Residual & \multicolumn{4}{|c|}{ MESSAGEPRESENTINAD } \\
\hline $\begin{array}{l}1 \\
2\end{array}$ & $\begin{array}{l}18 \\
24\end{array}$ & $\begin{array}{l}22.0 \\
22.0\end{array}$ & $\begin{array}{r}-4.0 \\
2.0\end{array}$ & & Observed $N$ & Expected $N$ & Residual \\
\hline 3 & $\begin{array}{l}24 \\
24\end{array}$ & 22.0 & 2.0 & 1 & 40 & 36.7 & 3.3 \\
\hline 4 & 23 & 22.0 & 1.0 & 2 & 38 & 36.7 & 1.3 \\
\hline 5 & 21 & 22.0 & -1.0 & & 32 & 36.7 & -4.7 \\
\hline Total & 110 & & & Total & 110 & & \\
\hline
\end{tabular}

Test Statistics

\begin{tabular}{|l|r|r|}
\hline & \multicolumn{1}{|c|}{ AGE } & \multicolumn{1}{|c|}{ MESSAGEPR } \\
\hline ESENTINAD \\
\hline df & $1.182^{2}$ & .945 \\
Asymp. Sig. & 4 & 2 \\
\hline
\end{tabular}

a. 0 cells $(0 \%)$ have expected frequencies less than 5 . The minimum expected cell

b. 0 cells $(0 \%)$ have expected frequencies less than 5 . The minimum expected cell

From the above SPSS calculation we infer that there is a significant relation between AGE and RESPONDENTS FEELING THE PRESENCE OF MESSAGE IN THE AD.

6.4.4. Is There a Relation between CREATIVITY IN THE AD and IN ITS ABILITY IN MAKING THE AD MESSAGE RELEVANT?

CREATMTY * MESSAGERELEVANCY Crosstabulation

\begin{tabular}{|c|c|c|c|c|c|}
\hline & & \multicolumn{3}{|c|}{ MESSAGERELEVANCY } & \multirow[b]{2}{*}{ Total } \\
\hline & & 1 & 2 & 3 & \\
\hline \multirow[t]{5}{*}{ CREATIVITY } & 1 & 9 & 14 & 7 & 30 \\
\hline & 2 & 10 & 9 & 6 & 25 \\
\hline & 3 & 5 & 5 & 6 & 16 \\
\hline & 4 & 7 & 10 & 5 & 22 \\
\hline & 5 & 5 & 6 & 6 & 17 \\
\hline Total & & 36 & 44 & 30 & 110 \\
\hline
\end{tabular}


CHI-SQUARE:

\begin{tabular}{|c|c|c|c|c|c|c|c|}
\hline \multicolumn{4}{|c|}{ CREATINTY } & & & & \\
\hline & Observed N & Expected N & Residual & \multicolumn{4}{|c|}{ MESSAGERELEVANCY } \\
\hline $\begin{array}{l}1 \\
2\end{array}$ & 30 & 22.0 & 8.0 & & Observed $N$ & Expected $N$ & Residual \\
\hline $\begin{array}{l}2 \\
3\end{array}$ & $\begin{array}{l}25 \\
16\end{array}$ & $\begin{array}{l}22.0 \\
22.0\end{array}$ & $\begin{array}{r}3.0 \\
-6.0\end{array}$ & 1 & 36 & 36.7 & -.7 \\
\hline 4 & 22 & 22.0 & .0 & 2 & 44 & 36.7 & 7.3 \\
\hline 5 & 17 & 22.0 & -5.0 & 3 & 30 & 36.7 & -6.7 \\
\hline Total & 110 & & & Total & 110 & & \\
\hline
\end{tabular}

\begin{tabular}{|c|c|c|}
\hline & CREATIVITY & $\begin{array}{l}\text { MESSAGERE } \\
\text { LEVANCY }\end{array}$ \\
\hline $\begin{array}{l}\text { Chi-Square } \\
\text { df }\end{array}$ & $\begin{array}{r}6.091= \\
4\end{array}$ & $\begin{array}{r}2.691^{\circ} \\
2\end{array}$ \\
\hline Asymp. Sig. & .192 & 260 \\
\hline
\end{tabular}

a. 0 cells $(0 \%$ ) have expected frequencies less than 5 . The minimum expected cell
frequency is 22.0 .

b. 0 cells $(0 \%)$ have expected frequencies less than 5 . The minimum expected cell
frequency is 36.7

From the above SPSS calculation we infer that there is a significant relation between CREATIVITY IN THE $\mathrm{AD}$ and IN ITS ABILITY IN MAKING THE AD MESSAGE RELEVANT.

6.4.5. Is There a Relation between GENDER OF THE RESPONDENT and THEIR ABILITY IN FEELING THE RELEVANCY OF THE MESSAGE IN THE AD? GENDER * MESSAGERELEVANCY Crosstabulation

\begin{tabular}{|ll|r|r|r|r|}
\hline & \multicolumn{3}{|c|}{ Mount } & \multicolumn{3}{|c|}{ MESSAGERELEVANCY } & \multirow{2}{*}{ Total } \\
\cline { 3 - 6 } & & 1 & 2 & 3 & 48 \\
\hline GENDER & 1 & 15 & 17 & 16 & 62 \\
& 2 & 21 & 27 & 14 & 110 \\
\hline
\end{tabular}

CHI-SQUARE:

GENDER

\begin{tabular}{|l|r|r|r|r|r|r|r|}
\hline & Observed N & Expected N & Residual \\
\hline 1 & 48 & 55.0 & -7.0 \\
2 & 62 & 55.0 & 7.0 & Observed N & Expected N & Residual \\
\cline { 5 - 8 } Total & 110 & & & 36 & 36.7 & -.7 \\
2 & & 44 & 36.7 & 7.3 \\
3 & 30 & 36.7 & -6.7 \\
\hline
\end{tabular}

Test Statistics

\begin{tabular}{|l|r|r|}
\hline & GENDER & MESSAGERE \\
\hline ChEMANGY \\
\hline df & $1.782^{\circ}$ & $2.691^{\circ}$ \\
Asymp. Sig. & 1 & 2 \\
\hline
\end{tabular}

a. 0 cells ( $0 \%$ ) have expected frequencies less than 5 . The minimum expected cell

b. o cells $(0 \%)$ have expected frequencies less than 5 . The minimum expected cell

From the above SPSS calculation we infer that there is a significant relation between GENDER OF THE RESPONDENT and THEIR ABILITY IN FEELING THE RELEVANCY OF THE MESSAGE IN THE AD.

6.4.6. Is There a Relation between ABILITY OF THE AD IN CONVEYING THE INTENDED MESSAGE and ITS ABILITY TO CHANGE THE OPINION AND PREJUDICE OF THE RESPONDENT ABOUT A PRODUCT OR SERVICE?

INTENDEDHESSAGE * CHANGEDOPINION Crosstabulation

\begin{tabular}{|ll|r|r|r|r|}
\hline \multirow{2}{*}{ count } & \multicolumn{3}{|c|}{ CHANGEDOPINION } & \multicolumn{1}{c|}{ Total } \\
\cline { 3 - 6 } & & 1 & 2 & 3 & 20 \\
& 1 & 10 & 5 & 5 & 24 \\
& 2 & 9 & 9 & 6 & 24 \\
& 3 & 7 & 10 & 7 & 23 \\
Total & 4 & 9 & 9 & 5 & 19 \\
\hline
\end{tabular}


CHI-SQUARE:

INTENDEDHESSAGE

\begin{tabular}{|c|c|c|c|c|c|c|c|}
\hline & Observed $N$ & Expected N & Residual & & & & \\
\hline 1 & 20 & 22.0 & -2.0 & \multicolumn{4}{|c|}{ CHANGEDOPINION } \\
\hline 2 & 24 & 22.0 & 2.0 & & Observed $N$ & Expected $N$ & Residual \\
\hline 3 & 24 & 22.0 & 2.0 & 1 & 43 & 36.7 & 6.3 \\
\hline 4 & 23 & 22.0 & 1.0 & 2 & 38 & 36.7 & 1.3 \\
\hline 5 & 19 & 22.0 & -3.0 & 3 & 29 & 36.7 & -7.7 \\
\hline Total & 110 & & & Total & 110 & & \\
\hline
\end{tabular}

Test Statistics

\begin{tabular}{|l|r|r|}
\hline & \multicolumn{1}{|c|}{$\begin{array}{c}\text { INTENDEDM } \\
\text { ESSAGE }\end{array}$} & \multicolumn{1}{c|}{$\begin{array}{c}\text { CHANGEDOP } \\
\text { INION }\end{array}$} \\
\hline Chi-Square & $1.000^{-}$ & $2.745^{\circ}$ \\
df & 4 & 2 \\
Asymp. Sig. & .910 & .253 \\
\hline
\end{tabular}

a. 0 cells $(0 \%)$ have expected frequencies less than 5 . The minimum expected cell frequency is 22.0 .

b. 0 cells $(.0 \%)$ have expected frequencies less than 5 . The minimum expected cell

From the above SPSS calculation we infer that there is a significant relation between ABILITY OF THE AD IN CONVEYING THE INTENDED MESSAGE and ITS ABILITY TO CHANGE THE OPINION AND PREJUDICE OF THE RESPONDENT ABOUT A PRODUCT OR SERVICE.

6.4.7. Is There a Relation between AGE and ABILITY OF THE AD IN CONVINCING THE RESPONDENT TO BUY THE PRODUCT? AGE * ADCONVINCEDTOBUYPRODUCT Crosstabulation

\begin{tabular}{|c|c|c|c|c|c|}
\hline & & \multicolumn{3}{|c|}{ ADCONVINCEDTOBUYPRODUCT } & \multirow[b]{2}{*}{ Total } \\
\hline & & 1 & 2 & 3 & \\
\hline \multirow[t]{5}{*}{ AGE } & 1 & 7 & 5 & 6 & 18 \\
\hline & 2 & 10 & 9 & 5 & 24 \\
\hline & 3 & 8 & 10 & 6 & 24 \\
\hline & 4 & 10 & 8 & 5 & 23 \\
\hline & 5 & 9 & 7 & 5 & 21 \\
\hline Total & & 44 & 39 & 27 & 110 \\
\hline
\end{tabular}

CHI-SQUARE:

\begin{tabular}{|c|c|c|c|c|c|c|c|}
\hline \multicolumn{4}{|c|}{ AGE } & & & & \\
\hline & Observed $N$ & Expected N & Residual & \multicolumn{4}{|c|}{ ADCONVINCEDTOBUYPRODUCT } \\
\hline $\begin{array}{l}1 \\
2\end{array}$ & $\begin{array}{l}18 \\
24\end{array}$ & $\begin{array}{l}22.0 \\
22.0\end{array}$ & $\begin{array}{r}-4.0 \\
2.0\end{array}$ & & Observed N & Expected N & Residual \\
\hline 3 & 24 & 22.0 & 2.0 & 1 & 44 & 36.7 & 7.3 \\
\hline 4 & 23 & 22.0 & 1.0 & 2 & 39 & 36.7 & 2.3 \\
\hline 5 & 21 & 22.0 & -1.0 & 3 & 27 & 36.7 & -9.7 \\
\hline Total & 110 & & & Total & 110 & & \\
\hline
\end{tabular}

Test Statistics

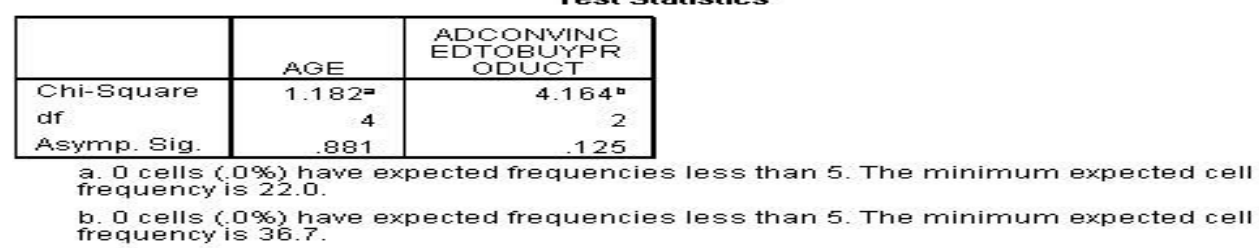

From the above SPSS calculation we infer that there is a significant relation between AGE and ABILITY OF THE AD IN CONVINCING THE RESPONDENT TO BUY THE PRODUCT. 


\section{Findings}

- Ads will be able to change the opinion of the customers about the product.

- Customers are likely to watch more of the ads which affect their opinion.

- Advertisement will easily convince the customer for the product

- Advertisements are the strong means of communication media to convey the intended message to the target group of customers

- The ads should neither be long nor be too short.

- They should be appealing and engaging the customers to involve in the advertisement.

\section{Conclusion}

Because buyers must act on the basis of incomplete information, they automatically and consciously incur a risk in every purchase and non-purchase decision. The size of the risk buyers perceive depends on the importance of the particular purchase and on the quantity of relevant information about the product category and the competing brands. A purchase decision can be considered as an optimization process through which buyers seek the product or the brand that will yield the greatest satisfaction. The choice process can be considered as the search for the most satisfying trade-off among brands that possess desirable attributes at different levels.

This view of the role of additional information in consumer purchase decision has implications for advertising. An advertisement reaching a potential buyer while the buyer is seeking information will have a greater impact, since the buyer is spared the time and effort needed to seek out this information himself and is less likely to turn to competing brand advertisements to obtain the additional information. In other words, buyers are generally more responsive to different brand advertisements while they are seeking information on these brands.

\section{References}

[1]. European Journal of Business and Management www.iiste.org ISSN 2222-1905 (Paper) ISSN 2222-2839 (Online) Vol 3, No.3

[2]. Effective advertising and its influence on consumer buying behavior Zain-Ul-Abideen.

[3]. THE ROLE OF ADVERTISING IN THE PURCHASE DECISION PROCESS Gîrboveanu Sorina-Raula University of Craiova, Faculty of Economics and Business Administration, 13 A.I.Cuza Craiova, sorinagirboveanu@yahoo.com, 0723-577-164

[4]. Australian Journal of Basic and Applied Sciences, 5(9): 1517-1524, 2011 ISSN 1991-8178 The Effectiveness of Online Advertising in Purchase Decision: Liking, Recall and Click1Yet-Mee Lim, 2Ching-Seng Yap and 1Teck-Chai Lau

[5]. Factors Influencing Through Television Advertisements on the Buying Decision of Rural People *Dr. S. Kamala saravanan.

[6]. Impact of Advertisement on Consumer Buying Behavior V.Prabakaran

[7]. The Impact of Advertisements on Children and Their Parents' Buying Behavior: An Analytical Study

[8]. Sultan Singh and Jaiman Preet Kaur

[9]. Examining Celebrity Expertise and Advertising Effectiveness in India Meenakshi Aggarwal-Gupta and Vriya Jha Dang

[10]. Kotler, Marketing Management - Analysis, Planning, Implementation, and Control, Prentice Hall, ISBN 0-13-603432-2, Ontario

[11]. Blackwell, R.; Miniard, P.W.; Engel, J.F. (2000), Consumer Behaviour, South-Western College Pub, ISBN 0030211085.

[12]. Arens, W.; Bovée, C. (2005), Contemporary Advertising, Mc-GrawHill Irwin, ISBN 0072964723, Burr Ridge

[13]. Bijmolt, T. H. A., Claassen, W., \& Brus, B. (1998). Children's Understanding of TV Advertising: Effect of Age, Gender, and Parental Influence. Journal of Consumer Policy, 21, 171-194.

[14]. Brassington, F., \& Pettitt, S. (2001). Principles of Marketing, 3rd Edition, Pearson Education, Prentice Hall.

[15]. Dunn, S.W. and A., Barban. 1987. Advertising, It's Role in Modern Marketing Advertising, Its Role in Modern Marketing. Hindsdale, Illinois, U.S.A.: Dryden Press

[16]. Latif, Abdul and Abideen, Zain Ul. (2011). Effects of Television Advertising on Children: A Pakistani Perspective. European Journal of Economics, Finance and Administrative Sciences, Issue, 30, pp. 38-49.

[17]. Proctor, R. and M. A. Stone. 1982. Marketing Research. Great Britain: Macdonald and Evans Ltd. Ifkin.

[18]. Stern, H. (1962). The Significance of Impulse Buying Today. Journal of Marketing, 26, 59-62.

[19]. Metha, A., 2000. Advertising attitudes and advertising effectiveness. Journal of Advertising Research, 40:67-72.

[20]. Sheoliha (2007), "Kids: A Bull's Eye for Advertisers Today", Advertising Express, June, pp. 39-42.

[21]. Mukherjee (2007), “Advertisements-Shaping a Child's Future: An Indian Insight",Advertising Express, October, pp. 27-30.

[22]. www.ebscosearch.com

[23]. http://www.acrwebsite.org/search/view-conference-proceedings.aspx? $\mathrm{Id}=8310$

[24]. http://www.csom.umn.edu/assets/125567.pdf

[25]. http://wiki.answers.com/Q/The role of advertising in consumer decision making in the telecommunication industry

[26]. http://www.jstor.org/discover/10.1086/314308?uid $=3738256 \&$ uid $=2129 \&$ uid $=2$ \&uid $=70 \& u i d=4 \&$ sid $=21101904571593$

[27]. http://www.rockresearch.com/understanding-consumer-decision-making-with-means-end-research

[28]. http://answers.mheducation.com/marketing/consumer-behavior/consumer-decision-making

[29]. http://marketsci.highwire.org/content/15/1/1.abstract

[30]. http://ajbr.org/Archives/Consumer\%20Decision-Making\%20Styles\%20Among\%20Indian\%20Students.pdf

[31]. http://papers.ssrn.com/sol3/papers.cfm?abstract id $=2203450$ 